\title{
The Effectiveness of Identifying Learning of the Information in Explanatory Texts By Using the SQ3R Method Based on the Reading Intensity of the XI Grade Students at Madrasah Aliyah
}

\author{
Zulaikhah Zulaikhah ${ }^{1 凶}$, Subyantoro Subyantoro ${ }^{2}$,Haryadi Haryadi ${ }^{2}$ \\ ${ }^{1}$ Madrasah Aliyah Negeri 2 Kudus, Indonesia \\ ${ }^{2}$ Universitas Negeri Semarang, Indonesia
}

\begin{tabular}{l} 
Article Info \\
\hline History Articles \\
Received: \\
August 2020 \\
Accepted: \\
Oktober 2020 \\
Published: \\
December 2020 \\
\hline Keywords: \\
Identifying \\
information learning, \\
SQ3R Learning \\
method, and reading \\
intensity
\end{tabular}

\begin{abstract}
Identifying learning of the information in explanatory text requires creativity in its implementation. One of the things that affect identifying learning of the information in explanatory text is the students' reading intensity. Therefore, it takes the most effective learning method to be applied and the learning method chosen is the SQ3R method. The purpose of this study was to explain the effectiveness of identifying learning of information in explanatory text by using the SQ3R method based on the reading intensity of the XI grade students at Madrasah Aliyah. The method used in this study was an experimental research design with a quasi-experimental factorial. The sample of this research is students of class IX MAN 2 Kudus. The collection of data uses identifying learning of the explanatory text information and reading intensity test to determine high or low reading intensity. Non-test data collection uses observation and photo documentation. The results of this study were (1) The SQ3R learning method was effective in identifying information in explanatory text for class XI students of Madrasah Aliyah with an increase of 12.23, from an average of 66.51 to 78.74 . This is evidenced by the sign value $=0.000<0.05$, which means that there is a significant difference in the learning outcomes of the experimental group pre-test post-test which is used the SQ3R learning method. Meanwhile, the ability to identify information in explanatory text to students with low reading intensity treated with the SQ3R method, and an average value is 67 . Identifying Learning of the information in explanatory text based on reading intensity of the XI grade students at Madrasah Aliyah by using the SQ3R is an effective learning method. The result of this learning has increased by 12.23 , from an average of 66.51 to 78.74 . This is evidenced by the sign value $=0.000<0.05$, which means that there is a significant difference in the learning outcomes of the experimental group pretest posttest using the SQ3R learning method.




\section{INTRODUCTION}

Learning material is material used by teachers learning activities at the classroom (Setyomurdian, 2018). One of the learning materials taught in class XI Madrasah Aliyah is explanatory text material. Explanatory text material is text that explains something about the process and formation of nature, social, culture (Hakim, 2018). In this material, there are basic competencies to identify information. In the learning of identify information ofthe explanatory text requires creativity in its implementation. Through identifying information, students can obtain information in reading. In addition, the recognition about identifying the information of explanatory text is important in learning of reading the explanatory text. In understanding explanatory text, students must think critically to find information and understanding of the structure, content, and language of it.

The success in learning is not only determined by teacher factors but also by other factors (Rinawati, 2019). One of the things that influences learning to identify information in explanatory text is the students' reading intesity. Therefore, a suitable or the most effective learning method is needed.

The accuracy in choosing and using the method greatly influences reading comprehension. If the method used is correct, it will support the result of understanding, but if the method used is not correct, it can disturb and reduce understanding of the text (Tampubolon, 2008).

In reading, a special method is needed so that reading can be effective and efficient. The special method consists of five stages, namely: survey, asking, reading, saying, and repeating (Subyantoro, 2009). The teacher does not only taught reading but also other language skills, namely listening, speaking and writing at that time. When the teacher reads a book, students will react by listening.

In addition, to choose an attractive method, the teacher must pay attention to student personality so that learning runs well
(Madasari, 2016). One of the students' achievements is influenced by reading interest. The low interest of reading in society is one of the impacts that are related to the reading ability of students at school (Nuriyah, 2014).

The learning method chosen in identifying explanatory text based on the reading intensity of students is the SQ3R method. The SQ3R method in Soedarso (2006) is a systematic reading process which includes the Survey, Question, Read, Recite, and Review stages.

From the various reading methods developed today, the SQ3R (Survey, Question, Read, Recite, and Review) method will be a focused thing in this research. The reason for choosing this method is because the SQ3R method has very possible steps to make it easier for students to understand the information contained in the text. The steps of the SQ3R (Survey, Question, Read, Recite, Review) Method in Haryadi (2006) are as follows,

a) Survey Task Stage, students survey the discourse. Give a few minutes for students to recognize the anatomy of the reading by read at glance.

b) Question Stage, making questions that exist in the mind of the reader based on the survey results. The questions that have been made will motivate students to answer questions during the reading stage.

c) Read Stage, students are assigned to read the discourse with focus as well as the students answer the questions that have been made in the third stage "question".

d) Recite Stage, students retell what has been obtained through notes that have been made using their own words. This implementation is through sharing with colleagues.

e) Review Stage, students re-examine the entire section.

It is hoped that students do not read again, but only see the titles, charts, outlines, review questions, and other means to ensure that they already have a complete picture of the discourse. After that, students summarize the 
contents of the text briefly according to their understanding.

Students are assigned to answer the evaluation questions without looking back at the contents of the discourse to determine the achievement of learning objectives. Then, they give confirmation of the work that has been done. The aim is to explain the effectiveness of identifying information learning in explanatory texts by the SQ3R method based on the reading intensity of the XI grade students at Madrasah Aliyah

The application of the SQ3R method in this study can help the legibility of a text because, before reading the text directly, students make preliminary observations to find an overview of the contents of the text (survey) at first. Second, there is a Question stage before reading, which is compiling a list of questions so that students are motivated. The enthusiasm of reading it is to answer those questions that arise in his mind. Third, the Read stage becomes fun and students are more focused and concentrated on the reading content. The fourth stage of Recite is a stage that allows students to remember longer the essence of the reading that they have read by re-expressing the contents of the reading both orally and in writing. The fifth stage is the Review stage, which is to review important things from the reading that have not been obtained.

The study on "Kajian Intensitas Membaca dan Menulis Peserta Didik Madrasah Aliyah Al Mu'min Muhammadiyah Tembarak 2011/2012" by Maksum (2013) contains reading and writing for students of MA Al-Mu'min Muhammadiyah Tembarak has become part of the culture which contains elements of cultural values, cultural systems, social systems, and physical culture.

The study on "Pengaruh Penerapan Metode SQ3R dan Teknik Klose terhadap Kemampuan Membaca Pemahaman Peserta Didik" was written by Suandi (2013). The results of the study concluded that the SQ3R method, the klose technique and the conventional method, had a significant effect on the reading comprehension ability of class VIII students of SMP Negeri SSN East Lombok Regency.
The study on the SQ3R method was carried out by Putri (2014) "Pengaruh Metode Pembelajaran SQ3R terhadap Hasil Belajar Bahasa Indonesia Kelas $V S D^{\prime \prime}$, the results of data analysis showed that there were significant differences in reading skills between students learning using the SQ3R learning method and students learning using conventional learning in class V SD Gugus 1 South Denpasar for the academic year 2013/2014. The learning innovation by using the SQ3R learning method can be used as an alternative to improve student learning outcomes in Indonesian subjects.

"Penerapan Metode SQ3R dalam Pembelajaran Kooperatif untuk Meningkatkan Hasil Belajar Fisika Pokok Bahasan Tata Surya pada Siswa Kelas VII SMP" was written by Masykur, et al. The results showed that the application of the SQ3R method in cooperative learning can improve student learning outcomes in the solar system topic. In the first cycle, the students' classical learning completeness reached 68\% with an average score on 66.3. In cycle II students' classical learning completeness increased to $88 \%$ with an average value on 73.8 .

Besides, the application of the SQ3R method in cooperative learning can also increase student learning activities during the learning process. In the first cycle, it was obtained $70 \%$ completeness of learning physical activity, 56\% mental activity and $60 \%$ emotional activity. In the second, the cycle completeness of learning physical activity increased to $88 \%$, mental activity $80 \%$ and emotional activity by $86 \%$. Thus, it can be concluded that the steps of implementing the SQ3R method in cooperative learning to improve learning outcomes in the solar system topic in grade VII junior high school students have been successful.

"Keefektifan Metode SQ3R Berbasis Teks Bernilai Budaya dalam Pembelajaran Membaca Pemahaman (Penelitian Subjek Tunggal Terhadap Siswa Thailand di Pondok Pesantren Husnul Khotimah Kuningan Jawa Barat)" was written by Wiradinata (2015). The results of this study indicate an incresed acquisition of students' scores in the objective test after they have participated in learning activities as an effort to 
improve their reading comprehension. It seems that there is an development that they get. This is obtained from the active participation between students and teachers when the SQ3R reading method is applied.

The study of the SQ3R method was carried out by Pratama (2016) "Pengaruh Metode SQ3R terhadap Hasil Belajar dan Minat Membaca di MAN 1 Pontianak". The results of data analysis show that there are differences in learning outcomes and reading interest between students who are taught using the SQ3R learning method and students who are taught using conventional learning methods. The result of the effect-size shows the SQ3R learning method has an effect of $26.12 \%$ on student learning outcomes.

The study of the SQ3R method was conducted by Asiri (2017) "The Effectiveness Of Using SQ3R to Teach Reading Skills." The results showed that students using the SQ3R reading comprehension strategy performed reading activities better than those who did not. By using the SQ3R strategy, students can maintain multiple pages of reading. Students can take notes in their own words, pronounce and check them while they are completing a chapter or other appropriate time. Teachers can use this strategy to make the reading process less difficult and more interesting.

One of the things that influence the identifying information learning in explanatory text is the reading intensity of students. According to Rahim (2008) people who have a strong interest in reading will be manifested in their willingness to get reading material and then read it on their own awareness. According to Tarigan (2008) to increase interest in reading, it can be done by:

1) taking time to read;

2) choosing good reading, in terms of criticality norms which include aesthetic, literary, and moral norms according to Dalman (2014), there are several ways to foster reading interest, or making reading as an everyday activity for someone who has necessity in reading will carry out reading activities every day. So, reading intensity can be interpreted as a person's ability to understand a text or discourse.

\section{METHODS}

The method used in this study was an experimental research design with a quasi experimental factorial. The design of this study used a quasi-experimental (nonequivalent pretest-posttest design). This study uses a moderator variable named reading intensity. The population of this study were students of class XI Madrasah Aliyah. The sample of this study is the students of class XI IPA 1 MAN 2 Kudus. The technique of sampling uses purposive sampling technique. The collection of test data through learning to identify informaation of the explanatory text and reading intensity tests to determine high or low reading intensity. The non-test data collection through observation and photo documentation.

The data analysis technique used in this study was the mean similarity test (t-test) to determine whether the ability to identify information in explanatory text using the SQ3R method was effective for students based on their reading intensity.

Before the sample of the two classes received treatment, the requirements test was carried out first. The test requirements in this study consisted of five, namely the normality test, homogeneity test, validity test, reliability test, and independent t-test.

The normality test was conducted to determine whether the pretest data for the experimental class and control class were normally distributed or not. The results of the complete normality pre-test can be seen in the following table.

\section{RESULTS AND DISCUSSION}

The results of the ability test to identify information in explanatory text in XI IPA 1 class at MAN 2 Kudus, the average value before using the SQ3R learning method, the average value of 66.51 . The learning process identifies information in explanatory text by using the SQ3R learning method based on the reading intensity of students in XI class at MAN 2 Kudus carried out in four meetings. 
The process of implementation of the reading intensity test carried out for students is fully carried out by the researcher after conducting post-test treatment. Students are given 32 questions. For each question, students are asked to choose one of the four options according to the category of their condition. The results of this test were then analyzed to determine the students' reading intensity, namely high reading intensity and low reading intensity.

Table 1. Result of the Test of Normality

Test of Normality

\begin{tabular}{lllllll}
\hline & \multicolumn{3}{l}{ Kolmogorov-Smirnova } & \multicolumn{3}{l}{ Shapiro-Wilk } \\
\cline { 2 - 7 } & Statistic & Df & Sig. & Statistic & df & Sig. \\
\hline Pre_Test & .100 & 73 & .069 & .975 & 73 & .165 \\
\hline
\end{tabular}

\section{a. Lilliefors Significance Correction}

The result of the normality test using the Kolmogorov Smirnov shows that the average value is 65.5616 . The standard deviation of the normality test is 7.95995 and the significance value is 0.069 . This shows a significance value exceeding 0.05 , which means that the data is

normally distributed. The homogeneity test is used to determine whether the two samples are homogeneous or not. The complete homogeneity test results can be seen in the following table.
The results of the ability test is to identify information in explanatory text in class XI IPA 1 MAN 2 Kudus, the average value after using the SQ3R learning method has increased rather than before getting treatment. The test results of the ability to identify information in explanatory text before using SQ3R has mean value of 66.51 . The test results of the ability to identify information in the explanatory text after using the SQ3R method has averaged 78.74.

(1)

Table 2. Result of the Test of Homogeneity of Variances

Test of Homogeneity of Variances

\begin{tabular}{llllll}
\hline & Levene Statistic & df1 & df2 & Sig. \\
\hline Nilai & Based on Mean & .361 & 1 & 71 & .550 \\
& $\begin{array}{l}\text { Based on Median } \\
\begin{array}{l}\text { Based on Median and with } \\
\text { adjusted df }\end{array}\end{array}$ & .205 & 1 & 71 & .652 \\
& .205 & 1 & 67.620 & .652 \\
Based on trimmed mean & .347 & 1 & 71 & .558 \\
\hline
\end{tabular}

The results of the homogeneity test using the Levine test obtained a significance value on 0.550 . This shows that the significance value exceeds 0.05 so that $\mathrm{H} 0$ is accepted, which means that the variance of the two groups is not significantly different or homogeneous. 
Table 3. Result of the Test of Equality Means

Independent Samples Test

\begin{tabular}{|c|c|c|c|c|c|c|c|c|c|c|}
\hline & & $\begin{array}{l}\text { Levene's } \\
\text { Equality } \\
\text { Variance }\end{array}$ & Test & $\begin{array}{l}\text { for } \\
\text { of }\end{array}$ & t-test for $\mathrm{E}$ & quality of & f Means & & & \\
\hline & & & & & & Sig. (2- & - Mean & Std. Error & $\begin{array}{l}95 \% \text { Con } \\
\text { Interval } \\
\text { Difference }\end{array}$ & $\begin{array}{l}\text { nfidence } \\
\text { of the } \\
\text { e }\end{array}$ \\
\hline & & $\mathrm{F}$ & Sig. & & Df & tailed) & Difference & Difference & Lower & Upper \\
\hline \multirow[t]{2}{*}{$\overline{\text { Nilai }}$} & $\begin{array}{l}\text { Equal } \\
\text { variances } \\
\text { assumed }\end{array}$ & .361 & .550 & & .92271 & .360 & 1.72030 & 1.86681 & -2.00202 & 5.44262 \\
\hline & $\begin{array}{l}\text { Equal } \\
\text { variances } \\
\text { not } \\
\text { assumed }\end{array}$ & & & \multicolumn{3}{|c|}{.91667 .786 .363} & 1.72030 & 1.87736 & -2.02613 & 5.46673 \\
\hline
\end{tabular}

The results of the pre-test data equality means test showed that the significance obtained on 0.360 . This means that the significance value exceeds 0.05 so that $\mathrm{H} 0$ is accepted, which means that there is no difference in the pretest mean of the two samples.
Hypothesis test is done by comparing the average pre-test and post-test results in learning to identify information in explanatory text using the SQ3R learning method.

Table 4. The Result of Pre-test and Post-test of the Effectiveness of Identifying Information Learning in Explanatory Texts by the SQ3R Method

\begin{tabular}{lll}
\hline Method & Pre-test Mean & Post-test Mean \\
\hline SQ3R & 66.51 & 78.74 \\
\hline
\end{tabular}

Based on the table above, it can be explained that the pre-test average of the experimental group was 66.51. After using the SQ3R learning method, the post-test mean score of the experimental group was 78.74. Based on the pre-test and post-test results of the experimental group there was a change of 12.23 .

It is relevant to Dhora's (2013) research which reveals that the SQ3R method is able to improve students' understanding abilities. The results of this study indicate that reading comprehension using SQ3R (Survey, Question, Read, Recite, Review) class VIII students of SMP Negeri 16 Bengkulu City can improve students' reading comprehension skills well.

It is relevant to $\mathrm{Al}$ Ghazo's research (2015) in his research journal article entitled
"The Effect of SQ3R and Semantic Mapping Strategies on Reading Comprehension Learning among Jordanian University Students". The results showed that the Semantic mapping and SQ3R strategy group performed better than the control group in the posttest (comprehension test) because the average score obtained by the experimental group (0.58) was higher than the average score obtained by the control group ( $0.5)$.

This is similar with Pratama (2015) in his journal article entitled "Pengaruh Metode SQ3R terhadap Hasil Belajar dan Minat Membaca di MAN 1 Pontianak". The results showed that there were differences in learning outcomes and reading interest between students who were taught using the SQ3R learning method and students who 
were taught using conventional learning methods.

In line with Priadi (2016) in his journal article entitled "Kemampuan Membaca Peserta didik dengan Menggunakan Metode SQ3R dan Gaya Belajar pada Mata Pelajaran Bahasa Indonesia". The results showed that the learning outcomes of reading skills in Indonesian subjects taught by the SQ3R method were higher than the learning outcomes of reading skills taught by the Quantum Reading method.

This is in accordance with Putri (2016) in her journal article entitled "Pengaruh Metode

Pembelajaran SQ3R terhadap Hasil Belajar Bahasa Indonesia Kelas $V S D$ ". The results showed a significant difference in language learning outcomes between students who took the SQ3R learning method and the learning outcomes of students who took conventional learning in V class SD students at Cluster 1 Denpasar Selatan in the Odd Semester in the 2013/2014 academic year. This states that there is an effect of the SQ3R (Survey, Question, Read, Recite, and Review) learning method on the Indonesian language learning outcomes of $\mathrm{V}$ class SD Gugus 1 South Denpasar students.
The results of this study are also relevant to research conducted by Fahmawati (2017) which explains that the SQ3R method is able to improve the critical thinking skills of high school students' learning outcomes.

It is still in line with Bakhtiar's research (2019) in his journal article "The Effectiveness of SQ3R Strategy in Teaching Reading," in this study shows an development in student achievement in the pretest and posttest in the experimental group after treatment.

Based on the results of the test of normality, it shows that the average value is 0.361 with a significance value is 0.550 . This shows that the significance value exceeds 0.05 , which means that the data is normally distributed. The homogeneity test results showed significance value is 0.361 . This shows that the significance value exceeds 0.05 so that $\mathrm{Ho}$ is accepted, which means that the variants of the two groups are not significantly different or homogeneous. The results of the average similarity test show that the significance value is 0.360 . This means that the significance value exceeds 0.05 so that Ho is accepted, which means there is no difference in the mean

Table 5. The Result of the Effectiveness of Information Identification Abilty in Explanatory Text through SQ3R Learning Method

\begin{tabular}{llll}
\hline Frequency of Reading & Method & Mean & $\mathrm{N}$ \\
\hline High & SQ3R & 82.22 & 27 \\
Low & SQ3R & 67 & 8 \\
\hline Total & SQ3R & 78.74 & 35 \\
\hline
\end{tabular}

Based on the table above, it can be seen that the 35 samples can be broken down into two parts, there are (1) the average value of students with high reading intensity using the
SQ3R method is 82.22 (2) The average value of students with low reading intensity using the SQ3R method of 67. 
Table 6. The Result of the Effectiveness of the Pre-test Post-test SQ3R Learning Method

Paired Samples Test

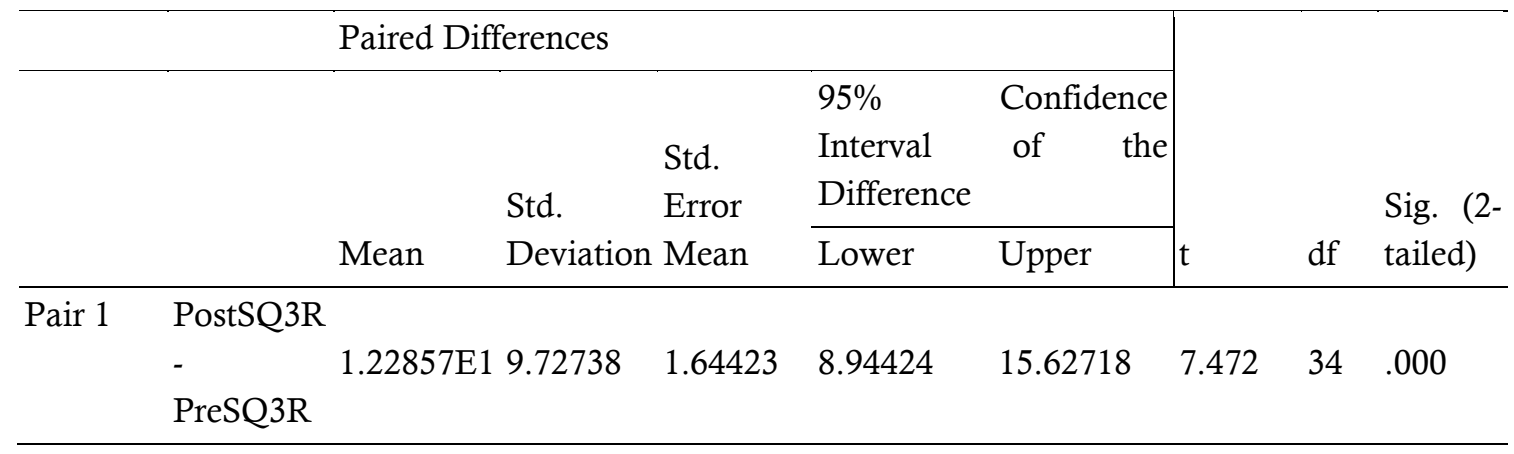

Based on the results of the table above, it can be seen that the results of the pre-test posttest in students who use the SQ3R learning method, the value of $t$-count $=7.472$ with a sign value $=0.000<0.05$. It means that there is a significant difference in the results of the pre-test post-test learning in the experimental group using the SQ3R learning method

Table 7. The Result of the Effectiveness of High and Low Students' Reading Intensity through SQ3R Learning Method

Paired Samples Test

\begin{tabular}{|c|c|c|c|c|c|c|c|c|c|}
\hline \multicolumn{7}{|c|}{ Paired Differences } & & & \multirow{4}{*}{$\begin{array}{l}\text { Sig. (2- } \\
\text { tailed) }\end{array}$} \\
\hline & & & \multirow{3}{*}{$\begin{array}{l}\text { Std. } \\
\text { Deviation }\end{array}$} & \multirow{3}{*}{$\begin{array}{l}\text { Std. } \\
\text { Error } \\
\text { Mean }\end{array}$} & $95 \%$ & Confidence & & & \\
\hline & \multirow{2}{*}{\multicolumn{2}{|c|}{ Mean }} & & & $\begin{array}{l}\text { Interval } \\
\text { Difference }\end{array}$ & of the & & & \\
\hline & & & & & Lower & Upper & $\mathrm{t}$ & $\mathrm{df}$ & \\
\hline $\begin{array}{l}\text { Pair Tinggi } \\
1\end{array}$ & SQ3R & 5.50000 & 2.07020 & .73193 & 3.76927 & 7.23073 & 7.514 & 7 & .000 \\
\hline
\end{tabular}

Based on the table above, it can be seen that the post-test results of students with high reading intensity using the SQ3R learning method, the sign value $=0.000<0.05$, which means that there is a positive difference in the SQ3R method. The posttest results of students with low reading intensity using the SQ3R learning method with sign $=0.095>0.05$, which means that there is no significant difference in learning outcomes in the low reading intensity group using the SQ3R learning method

\section{CONCLUSION}

Learning identifies information in explanatory text for students with high reading intensity who are treated by the SQ3R method is better, it achieve the average value on 82.22 This is evidenced by the value of sign $=0.000<0.05$ which means there is a significant difference in learning outcomes in the high-intensity group by using the SQ3R method. The ability to identify information in explanatory text of low reading intensity students who were treated by the SQ3R method reached an average value on 67.This is evidenced by sign $=0.95>0.05$, which means there is no significant difference in learning outcomes in the down-intensity group with the SQ3R method.

Based on the results of the pre-test and post-test of the ability to identify information in the explanatory text using the SQ3R method, the pre-test mean score of students before using the SQ3R method was 66.51 and the post-test average score of students after using the SQ3R method was 78.74. There is a development in 80 
students' learning outcomes after using the SQ3R learning method on 12.23.

Based on the explanation above, it is concluded that the SQ3R learning method is effective in learning to identify information in explanatory text for class XI students of Madrasah Aliyah with an increasing on12.23. started from the value is 66.51 to 78.74 . This is evidenced by the sign value $=0.000<0.05$, which means that there is a significant difference in the pre-test post-test learning outcomes of the experimental group using the SQ3R learning method.

Based on the results of this study, it is suggested that (1) the educators need to apply the SQ3R learning method in learning to identify the information in explanatory text, because this method has been proven to be effective in learning to identify information in class XI students at Madrasah Aliyah; (2) the educators should be creative and innovative in using various kinds of learning methods that are suitable for the situation and conditions of students; hence, they are more motivated to be active and creative and the results in the learning process to be more enjoyable; (3) for other researchers, the further research is needed on the SQ3R learning method in Indonesian language learning on other basic competencies; and (4) the determinants of educational policy, it is hoped that the results of this research can be used as input in order to improve the quality of educators.

\section{REFERENCES}

Al Ghazo, Abeer. (2015). The Effect of SQ3R and Semantic Mapping Strategies on Reading Comprehension Learning among Jordanian University Students. International Journal of English and Education. ISSN: 2278-4012, Volume:4, Issue:3, July 2015.

Asiri, Ahmad \& Mowaffaq M Momani.( 2017). The Effectiveness Of Using SQ3R to Teach Reading Skills. Asian Journal of Educational Research Vol. 5, No. 1, 2017
ISSN 2311-6080 Multidisciplinary Journals www.multidisciplinaryjournals.com.

Bakhtiar, Hestiana. (2019). The Effectiveness Of SQ3R Strategy in Teaching

Reading. Masters thesis, Universitas Negeri Makassar.

Dhora, Tri. (2013). Peningkatan Kemampuan Membaca Pemahaman Peserta didik dengan Menggunakan Metode SQ3R (Survey, Question, Read, Recite, Review). Tesis. Universitas Bengkulu.

Dyson, Many C. and Mark Haselgrove. (2000). The Effects of Reading Speed and Reading Patterns On The Understanding of Text Tead from Screen. Journal of Research In Reading Volume 23, Issue 2: Department of Typography and Graphic Communication, The University of Reading, UK.

Fahmawati, dkk. (2017). Pengaruh Metode Pembelajaran Survey, Question, Read, Recite, Review (SQ3R) dan Kemampuan Berpikir Kritis terhadap Hasil Belajar Peserta Didik SMA. Jurnal UNS vol 10 No 2

p-ISSN: 1693-265X e-ISSN: 2549-0605.

Fitria. 2011. Kelebihan-dan-kelemahan-metode SQ3R. tersedia pada http://www.fitria507.blogspot.com/2011 /12/kelebihan-dan-kekurangan metode.html Jumat, 09 Desember 2018.

Hakim, Lukman \& Subyantoro. (2019). Learning Writing Explanatory Text Using Group Investigation Models Based on Learning Style. Seloka: Jurnal Pendidikan Bahasa dan Sastra Indonesia 7 3) (2018) : $259-266$

Haryadi. (2006). Pokok-Pokok Keterampilan Membaca. Semarang: PKUPT. UNNES.

Haryadi. (2006). Retorika Membaca: Model, Metode, dan Teknik. Semarang: Rumah Indonesia.

Madasari, Kurnia Asti \& Mimi Mulyani. (2016) Keefektifan Metode Eja dan Metode SAS Berdasarkan Minat Belajar dalam Pembelajaran Keterampilan Membaca dan Menulis Permulaan pada Siswa Kelas 1 Sekolah Dasar. Seloka: Jurnal 
Pendidikan Bahasa dan Sastra Indonesia 5 (2) (2016).

Masykur, Siti Khanafiyah, \& Langlang Handayani. (2006). Penerapan Metode SQ3R dalam Pembelajaran Kooperatif untuk Meningkatkan Hasil Belajar Fisika Pokok Bahasan Tata Surya pada Siswa Kelas VII SMP. Jurnal Pend. Fisika Indonesia Vol. 4, No. 2, juli 2006.

Maksum. (2013). Kajian Intensitas Membaca dan Menulis Peserta didik Madrasah Aliyah Al Mu'min Muhammadiyah Tembarak Temanggung Tahun 2011/2012. Tesis: Universitas Muhammadiyah Surakarta.

Nurriyah. (2014). Pembelajaran Keterampilan Membaca Intensif Paragraf dengan Model Pengembangan Konsep Melalui Aktivitas Bahasa (PKMAB) dan Model Pendahuluan, Penganalisisan, Pengulangan (P3) pada Siswa SMP dilihat dari Karaktersosial dan Mandiri. Seloka: Jurnal Pendidikan Bahasa dan Sastra Indonesia (2) (2014).

Priadi, Sastra. (2016). Hubungan antara Kemampuan Membaca Peserta didik dengan Menggunakan Metode SQ3R dan Gaya Belajar pada Mata Pelajaran Bahasa Indonesia. Medan: Tesis.

Putri, I Gusti Ayu Cahyani. (2016). Pengaruh Metode SQ3R terhadap Hasil Belajar Bahasa Indonesia Kelas V SD. Jurnal Mimbar PGSD Universitas Pendidikan Ganesha. Undiksa Vol 2 No 1.

Rinawati, Evi \& Subyantoro. (2019). The Form of Teachers' Reinforcement in Learning Interaction of Indonesian Language Learning of Curriculum 2013 in Public
Senior High School 1 Jepara. Seloka: Jurnal Pendidikan Bahasa dan Sastra Indonesia 8 (1) (2019) : 56 - 65

Setyomurdian, Ardika Novi \& Subyantoro. 2018. The Development of Learning Material of Reading Complex Prosedure Text with CLIL Aproach for Vocational High School Students. Seloka: Jurnal Pendidikan Bahasa dan Sastra Indonesia 7 (2) (2018) : 185 - 190.

Suandi, Muhaji N. \& I.B Putrayasa. 2013. Pengaruh Penerapan Metode SQ3R dan Teknik Klose terhadap Kemampuan Membaca Pemahaman Peserta didik. eJournal Program Pascasarjana Universitas Pendidikan Ganesha Program Studi Pendidikan Bahasa dan Sastra Indonesia (Volume 2 Tahun 2013).

Subyantoro. (2009). Pelangi Pembelajaran Bahasa. Semarang:Universitas Negeri Semarang. Sukestiyarno.(2012). Olah Data Penelitian Berbantuan SPSS. Semarang: UNNES Press.

Tampubolon, D.P. (2008). Kemampuan Membaca: Teknik Membaca Efektif dan Efesien. Bandung: Angkasa

Tarigan, Henry Guntur. (2008). Membaca sebagai Suatu Keterampilan Berbahasa. Bandung: Angkasa.

Wiradinata, Rochanda, Jaja, \& Apippudin. (2015). Keefektifan Metode SQ3R Berbasis Teks Bernilai Budaya dalam Pembelajaran Membaca Pemahaman (Penelitian Subjek Tunggal Terhadap Siswa Thailand di Pondok Pesantren Husnul Khotimah Kuningan Jawa Barat). Tuturan, Vol. 4, No. 1, Januari 2015: 722

737. 